\title{
Developing a protocol whole sediment toxicity testing with the polychaete Armandia agilis
}

\author{
SAEs, R.V.S.T. ${ }^{1}$; Moreira, L.B. ${ }^{2}$; Davanso, M.B. ${ }^{2}$; \\ Perina, F.C. ${ }^{3} \&$ ABEsSA, D.M.S ${ }^{1,2}$

\begin{abstract}
${ }^{1}$ Institute of Marine Sciences - Federal University of Ceará - Ave. Abolição, 3207, Meireles. ZIP 60135-081, Fortaleza/CE, Brazil. São Vicente/SP, Brazil.
\end{abstract} \\ ${ }^{2}$ São Vicente Campus - State Paulista University Julio de Mesquita Filho - Sq. Infante Dom Henrique, s/n., Parque Bitarú. ZIP 11330-900, \\ ${ }^{3}$ Oceanographic Institute - University of São Paulo - Sq. Oceanográfico, 191, Cidade Universitária. ZIP 05508-120, São Paulo/SP, Brazil.
}

Received December 20, 2017; Accept July 06, 2018

\begin{abstract}
Sediments constitute a key compartment of coastal and marine ecosystems. They also constitute the ultimate sink for most of the chemical substances and a source of contamination to the benthic fauna. In this study, we aimed to develop a protocol for acute toxicity tests using the polychaete Armandia agilis as a model species. To achieve that, we evaluated the species tolerance to the salinity of overlying water (in the presence and absence of sediment), the tolerance to sediments with different particle sizes, the sensitivity to reference substances (potassium dichromate $-\mathrm{K}_{2} \mathrm{Cr}_{2} \mathrm{O}_{7}$, zinc sulfate $-\mathrm{ZnSO}_{4}$; and Sodium Dodecyl Sulfate - SDS), and the responses to clean and contaminated sediments. The species survives in several latitudes on the American coast (North Carolina, Gulf of Mexico, and South-Southeast of Brazil) in different haline conditions (above 20) in typically sandy textures. In Ilhabela (SE Brazil), the species was available throughout the year. The $\mathrm{LC}_{50}-48 \mathrm{~h}$ values calculated to the $\mathrm{K}_{2} \mathrm{Cr}_{2} \mathrm{O}_{7}, \mathrm{ZnSO}_{4}$, and SDS, were 20.94 (33.38-14.04); 4.25 (7.66-2.98); 4.90 (6.59-3.84) mg L-1 respectively; thus $A$. agilis can be considered as sensitive as other benthic organisms. The responses of $A$. agilis to environmental sediments were similar to those exhibited by the amphipod Tiburonella viscana, showing that this polychaete is responsive to contaminated sediments. Armandia agilis can be considered a promising organism to be used in sediment toxicity tests.
\end{abstract}

Keywords: Bioassays; sediment; reference substance; test-species; contamination.

\section{INTRODUCTION}

Ecotoxicological approaches include methods to investigate the biological effects of chemical substances on non-target organisms or their interactions with the environment at different levels of biological organization (Blaise, 1984; Chapman, 2002). A toxicity test consists in using a biological model (test organism), exposed to an environmental sample or a chemical of interest, in a bioassay, in order to evaluate the adverse effects related to such exposure (ASTM, 2007; USEPA, 1996). These types of bioassay are sensitive and provide an overview of integrated effect caused by complex mixtures of toxic substances and their interactions (ASTM, 2004; Long et al., 1995), and constitute a recommended strategy to assess the effects of multiple stressors under the Environment Risk Assessments frameworks (Beyer et al., 2014; Chapman and Smith, 2012; Long et al., 2001). Toxicity tests have been used worldwide to assess sediment quality (Chapman, 2007; Gomiero et al., 2013; Senese et al., 2010; Torres et al., 2009); the strategy of studying sediments is justified because they constitute the ultimate sinks for many substances introduced into the aquatic environment (Burton Jr. and Scott, 1992; Chapman, 1989; Kwok et al., 2014). The most used protocols include testing the toxicity of both the whole-sediment and liquid phases extracted from the sediments. 
Amphipods and polychaetes are the most commonly used organisms for sediment testing around the world (Lamberson et al., 1992; Lewis et al., 2008). In Brazil, the development of ecotoxicological methods with marine and estuarine species is recent, and a much-reduced number of biological models are already available for sediment testing. The amphipods Tiburonella viscana, Leptocheirus plumulosus, Grandidierella bonnieroides, Hyale nigra and $H$. youngi have been used to assess the acute toxicity of whole sediment samples (e.g., Abessa et al., 2005; 2008; ABNT, 2016; Buruaem et al., 2013; Dewitt et al., 1996; Maranho et al., 2009; Melo and Nipper, 2007; Molisani et al., 2013; Nilin et al., 2013), as well as the tannaidacea Kalliapseudes schubartii (e.g., Brendolan, 2004; Perina, 2009). In the same way, meiobenthic copepods Nitocra sp (e.g., Lotufo and Abessa, 2002; Nilin et al., 2013; Sousa et al., 2012) and Tisbe biminiensis (e.g., Araújo-Castro et al., 2009; Lavorante et al., 2013; Oliveira et al., 2014) have been used to test the chronic toxicity of sediments. However, given the continental scale of Brazilian coast, which presents different environments and high diversity of species, it is necessary to standardize new methods and organisms to be used as model in sediment toxicity tests.

Benthic organisms are the natural candidates to be new test species, as they play a key role in ecological processes involving sediments and represent the exposure in the sedimentary environment. Particularly polychaetes present a large variety of strategies and feeding types, occupying different levels of the marine food web (Fauchald and Jumars, 1979). Some species of polychaetes can rapidly colonize stressed environments by either natural or anthropogenic factors due to their short life cycle, high fertility and reduced body size (Dauvin and Ruellet, 2009; Ugland et al., 2008), being thus important indicators of ecological status in marine and estuarine areas. Literature has recommended polychaetes in ecotoxiclogical studies (Ahrens et al., 2001; Allen et al., 2007; Bay et al., 2007; Bat, 2005; Dean, 2008; Dillon and Moore, 1993; French and Turner, 2008; Galloway et al., 2010; Lewis et al., 2008; Lewis and Watson, 2012; Matthiessen et al., 1998; Mauri et al., 2003; McDonald and Haynes, 2001; Pesch, 1979; Ramos-Gómez et al., 2008; Sun et al., 2009; Watson et al., 2013). .

Meador and Rice (2001) used the opheliid Armandia brevis, typical of temperate environments, to evaluate the toxic effects of tributyltin (TBT). For tropical environments another species from the same genus, Armandia agilis, has a high abundance along the Brazilian coast (Amaral, 1980; Amaral et al., 2010; Amaral and Borzone, 2008; Kuk-Dzul et al., 2012; Omena et al., 2012; Silva, 2007; Venturini et al., 2008) and could be considered a potential test organism for sediment toxicity tests.

The primary objective of this study is to develop a protocol for testing the acute toxicity of whole sediment samples by using the polychaete Armandia agilis as a model species. Lethal effects related to the species sensitivity to physicalchemical variables, such salinity and grain size of sediments, and to different types of contaminants were assessed and a validation by testing environmental samples was performed.

\section{MATERIAL AND METHODS}

Similarly to other authors (Anderson et al., 1998; Bat and Raffaelli, 1998; Millward et al., 2005), we adopted the strategy of adapting the existing protocols for whole sediment toxicity testing with amphipods, in special the native species Tiburonella viscana (Melo and Abessa, 2002; Melo and Nipper, 2007), and the polychaetes Nereis (Neanthes) arenaceodentata (Family Nereididae) and Polydora cornuta (Family Spionidae), which are used by the Canadian Environmental Agency (EC, 2001).

\section{Biological aspects of the Test-organism}

The polychaete Armandia agilis (first description Andrews - 1891) (Figure 1) belongs to the Opheliidae family (first description Malmgren - 1867), which organisms are characterized by presenting gills in almost all segments, usually as simple cirriform structures. Their head is generally formed by a conical, short or elongated prostomium, with a pair of retractable nuchal organs in the posterior edge. The majority of the parapodia are biramous and present setae. $A$. agilis is characterized by the presence of lateral and ventral sulcus over the entire body (Silva, 2007) and by presenting about 35 or more setigers. The species presents a short prostomium with small palpodium, and thick gills starting from the second setiger, with small patches of pigment randomly distributed. The individuals present 20 pairs of lateral eyes starting the seventh or eighth segment (Nonato and Luna, 1970; Silva, 2007).

The species inhabits the first layers of the sediment and its feeding behavior may be classified as deposit feeders, including sediment particles (Tamaki, 1985b). Thus, we could expect that $A$. agilis may be exposed to sediment contaminants via respiratory, dermal contact and food ingestion. The species is common in the Atlantic coast from North Carolina, Gulf of Mexico to the Northeast, Southeast and South of Brazil (Amaral et al., 2010; Nonato and Luna, 1970), and was also reported to the Japanese coast (Tamaki, 1985a; Tamaki, $1985 b)$. The juveniles can reach up to $1.6 \mathrm{~cm}$ long in the Pacific (Tamaki, 1985b), but in the Atlantic Ocean juveniles are smaller (about $0.9 \mathrm{~cm}$ long), with a whitish coloring feature, being recruited during the summer. The adults have $1.8 \mathrm{~cm}$ of average size with a sparkling color.

\section{Organisms sampling and Acclimating}

The organisms were collected at Engenho D'Água beach $\left(23^{\circ} 47,324^{\prime} \mathrm{S} ; 4^{\circ} 21,527^{\prime} \mathrm{W}\right)$ in Ilhabela (São Paulo State, Brazil). This region is relatively well studied, with high marine biodiversity and presents low levels of environmental contamination (Abessa et al., 2008; Melo and Nipper, 2007). A stainless steel manual dredge (with $1 \mathrm{~mm}$ mesh) was used to collect the individuals from the region between the intertidal and subtidal zones. In field, the organisms were separated and transferred to plastic 


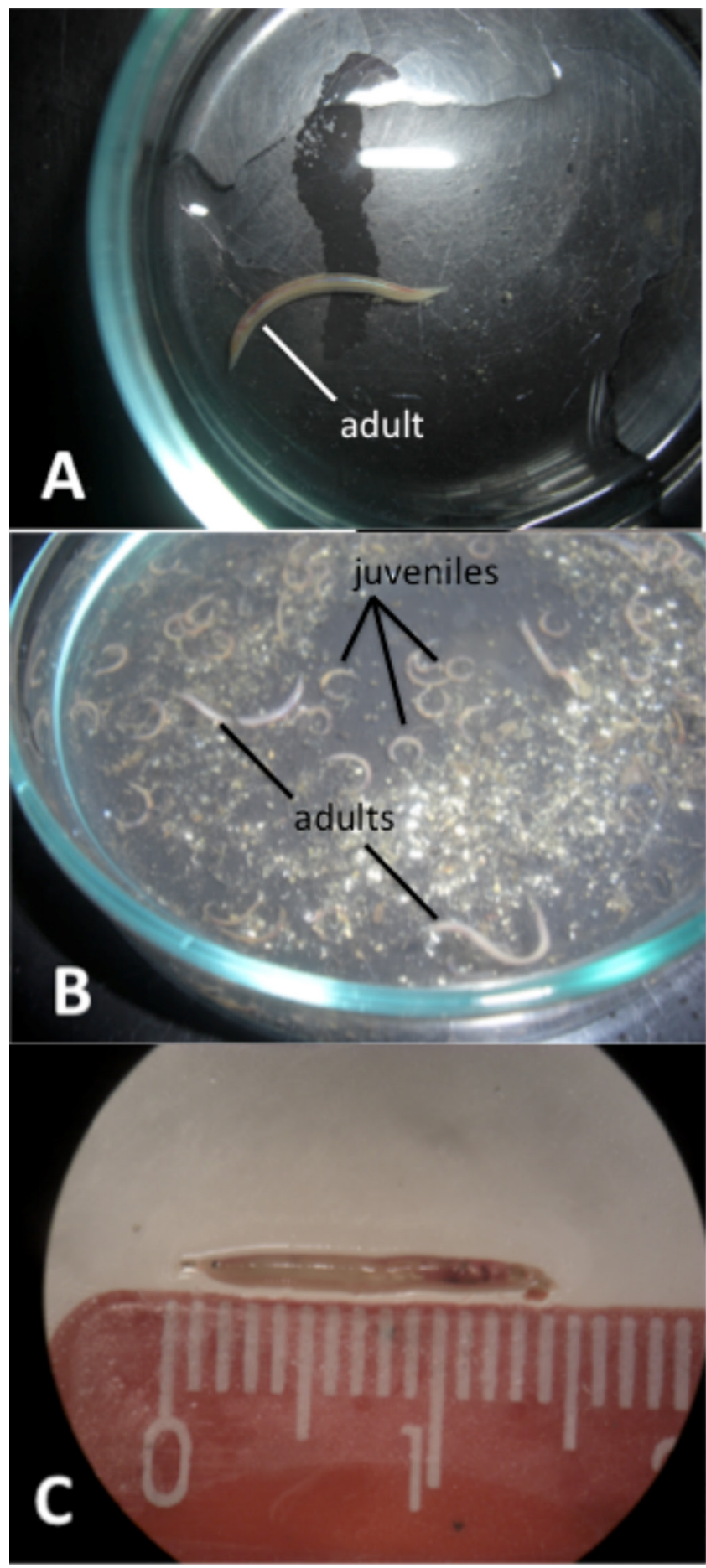

Figure 1: Juveniles and adults of Armandia agilis. A) An adult specimen. B) Adult organisms and juveniles between the sand grains. C) Adult of A. agilis (cm).

flasks filled with seawater, and sediments were collected to be used in the experiments. Further, the animals were sorted in laboratory and placed in tanks containing clean seawater and sediment from the collection site, which were maintained at $25 \pm 2{ }^{\circ} \mathrm{C}$ and photoperiod (12h:12h - light/ dark). The acclimation period before the experiments lasted between 2 and 5 days, and during this period, the organisms were not fed.

\section{Experimental design}

Different experiments were conducted to evaluate the tolerance of the species to different salinities of overlying water (in the presence and absence of sediment), and to different textures of sediments, as well as their sensitivity to reference substances and their response when exposed to environmental samples with different levels of contamination and textures; the responses to environmental samples were compared to those obtained to the amphipod $T$. viscana. Juveniles were separated from the sediment by using a $300 \mu \mathrm{m}$ mesh, and used in the different bioassays. At the end of the tests, the number of survivors in each replicate was recorded. In all the experiments, the physicochemical parameters (dissolved oxygen, $\mathrm{pH}$ and salinity) in the overlying water were monitored according to ABNT (2016) by using digital probes and a portable refractometer.

\section{Tolerance to Water Salinity}

In the first experiment, the exposure system was set in $500 \mathrm{~mL}$ polyethylene flasks as test chambers, filled with $300 \mathrm{~mL}$ test solution (aqueous exposure only), and the tolerance to different salinities of the overlying water, in absence of sediment, was evaluated. Three replicates were prepared for each salinity ( $\mathrm{S}=15,20,2530,35$ and 40$)$; the treatments were obtained by diluting clean filtered seawater in ultra-filtered water (Milli-Q system), except for the salinities of 35 (natural salinity of the seawater used) and 40 (this salinity was prepared by adding artificial sea salts to the filtered seawater). Five organisms were introduced in each replicate, and the replicates were maintained without aeration and under with constant lighting. The mortalities were recorded at each $24 \mathrm{~h}$ interval, and the experiment lasted 96h. Significant differences were tested between salinity groups by using one-way ANOVA followed by Tukey test, with the purpose of identifying the range of salinity that does not affect the organisms. To test the exposure time a student $t$ '-test for paired-samples were applied due to the dependence on the exposure time periods.

A second experiment was conducted to assess the tolerance to salinities, but in the presence of sediments. This experiment used the same protocol for preparing the overlying waters with different salinities $(15,20,2530,35$ and 40), but had the addition of $150 \mathrm{~g}$ control sediment in each of the three replicates of each treatment. Five juvenile individuals were added in each replicate, and the set was kept under constant aeration, temperature $\left(25 \pm 2^{\circ} \mathrm{C}\right)$ and lighting. The test lasted 10 days, and at the end of the assay, sediments were sieved and the number of surviving polychaetes in each replicate was recorded. The survival rates in each treatment were compared by using the two-factor ANOVA followed by the Bonferroni test (with $\mathrm{p}<0.05$ ).

\section{Tolerance to sediment textures}

To determine the influence of sediment grain size on the polychaetes survival, an experiment exposing the animals 
to different sediment textures was set. The control sediment from Ilhabela was washed to remove the effect of the salt, and then dried at $55^{\circ} \mathrm{C}$. Then, the sediment was sieved through a set of meshes, selecting different grain sizes: gravel, coarse, medium, fine and very fine sands, in accordance with the Wentworth scale (Wentworth, 1922). Separation of muddy particles (silt + clays) was made by wet sieving followed by the separation of sieved fraction; this fraction was then dried at $40^{\circ} \mathrm{C}$ and stirred before use in the tests.

Three replicates were set up for each grain size fraction, using $500 \mathrm{~mL}$ polyethylene flasks as test chambers. Each replicate contained $150 \mathrm{~g}$ of sediment and $300 \mathrm{~mL}$ of filtered natural seawater (salinity $=35$ ). Five organisms were introduced into each replicate, and the system was maintained for 10 days, under constant aeration and lighting. The sediments were sieved and the number of survivors was recorded at the end of the assay. The results were analyzed by one-way ANOVA, followed by the Dunnett's t'-test, in order to compare the survival in each textural class with the reference sediment (control) from Ilhabela, which had the following characteristics (average values), after being previously sieved in a $0.5 \mathrm{~mm}$ mesh: $91.64 \%$ sand, $1.3 \%$ Organic Matter; $8.23 \%$ $\mathrm{CaCO} 3$ and absence of toxicity.

\section{Sensitivity to reference substances}

The sensitivity of $A$. agilis was tested for the following reference substances (Table 1), which are recommended in international protocols (ASTM, 2000; EC, 2001): potassium dichromate $\left(\mathrm{K}_{2} \mathrm{Cr}_{2} \mathrm{O}_{7}\right)$, zinc sulfate heptahydrated $\left(\mathrm{ZnSO}_{4} \cdot 7 \mathrm{H}_{2} \mathrm{O}\right)$ and the detergent SDS - sodium dodecyl sulfate $\left(\mathrm{C}_{12} \mathrm{H}_{25} \mathrm{SO}_{4} \mathrm{Na}\right)$. Stock solutions were prepared from pure salts, which were diluted in filtered seawater, and only aqueous solutions were tested (ASTM, 2000), considering six concentrations per substance (Table 1). The tests had 96h duration, and at the end the polychaetes survival was used as endpoint. Five experiments were performed with each compound in order to provide enough data to the establishment of an initial sensitivity control-chart.

The test chambers consisted of $250 \mathrm{~mL}$ polyethylene flasks containing $150 \mathrm{ml}$ of test solution, in triplicate. Five organisms were added to each chamber, and the system was kept under constant lighting and at $25 \pm 2^{\circ} \mathrm{C}$, with no aeration. Mortalities were checked every 24-hour cycle, and when the experiments were finished. The results were analyzed by the Trimmed Spearman-Karber method with Abbott's correction (Hamilton et al., 1977) to obtain the lethal concentrations to $50 \%$ of the organisms after 24 and 48 hours of exposure (EC, 2001).

\section{Responses to environmental samples}

The toxicity of environmental sediment samples was tested to A. agilis and also with the amphipod Tiburonella Viscana, in order to allow a comparison of the polychaete response with a species classically used to evaluate whole sediment toxicity.

The sediments were collected close of the Mucuripe Harbor, Fortaleza, Brazil $\left(3^{\circ} 42.728^{\prime} \mathrm{S}\right.$; $\left.38^{\circ} 28.514^{\prime} \mathrm{W}\right)$ (Figure 2). This study site was selected because of the sediment characteristics (sandy sediments) and the presence of contamination and toxicity, as reported by Buruaem et al. $(2012 ; 2016 ; 2017)$. The samples were collected in two campaigns, the first during the Mucuripe dredging process in January 2011, in the stations MD1 to MD3. The second campaign was carried out after the dredging has finished, in July 2011, at the MD1' to MD3'. The stations MD1 and MD2 were located in front of the commercial docks, under the influence of effluent discharges and impacts from the docking ships and piers of the oil refinery; MD3 was situated in an area outside the port area. The reference sediments (control) were collected at Ilhabela (SP) and Icapuí (CE), about $200 \mathrm{~km}$ eastward of Mucuripe (Table 2). Sediment samples were collected using a VanVeen grab $\left(0.026 \mathrm{~m}^{2}\right)$. In the laboratory, grain size distribution was measured by a wet sieving in $0.063 \mathrm{~mm}$ mesh followed by dry sieving of sediments. The sediments textures were classified according to Folk and Ward (1957). Levels of $\mathrm{CaCO}_{3}$ were obtained by $\mathrm{HCl}$ digestion and gravimetric method (Gross, 1971), and organic matter $(\mathrm{OM})$ contents were measured by the method of combustion and gravimetric (Luczak et al., 1997).

For both species, the experiment followed the protocols described to T. viscana (ABNT, 2016; Melo and Abessa, 2002; Melo and Nipper, 2007). Three replicates were prepared for each sediment sample, in $1 \mathrm{~L}$ polyethylene chambers containing $200 \mathrm{~g}$ of sediment and $750 \mathrm{~mL}$ of clean seawater. Ten organisms $(A$.

Table 1: Stoichiometric conversions using the molecular mass of stock solutions of sodium dodecyl sulfate ( $\mathrm{SDS}$ ); potassium dichromate $\left(\mathrm{K}_{2} \mathrm{Cr}_{2} \mathrm{O}_{7}\right)$; zinc sulfate $\left(\mathrm{ZnSO}_{4} \cdot 7 \mathrm{H}_{2} \mathrm{O}\right)$; and the estimated concentrations for $\mathrm{Cr}$ and $\mathrm{Zn}$, respectively.

\begin{tabular}{ccccc}
\hline \multicolumn{5}{c}{ Nominal concentrations of the reference substances $\left[\mathrm{mg} \mathrm{L}^{-1}\right]$} \\
\hline $\begin{array}{c}\mathrm{K}_{2} \mathrm{Cr}_{2} \mathrm{O}_{7} \\
(\mathrm{MM} 294.20 \mathrm{~g} / \mathrm{mol})\end{array}$ & $\begin{array}{c}\mathrm{Cr} \\
(\mathrm{MM} 52.00 \mathrm{~g} / \mathrm{mol})\end{array}$ & $\begin{array}{c}\mathrm{SDS} \\
(\mathrm{MM} 288.38 \mathrm{~g} / \mathrm{mol})\end{array}$ & $\begin{array}{c}\mathrm{ZnSO}_{4} \\
(\mathrm{MM} 287.40 \mathrm{~g} / \mathrm{mol})\end{array}$ & $\begin{array}{c}\mathrm{Zn} \\
(\mathrm{MM} \mathrm{65.40} \mathrm{g/mol})\end{array}$ \\
\hline 50.00 & 8.84 & 25.00 & 10.00 & 2.28 \\
25.00 & 4.42 & 10.00 & 5.00 & 1.14 \\
12.50 & 2.21 & 5.00 & 1.00 & 0.23 \\
6.25 & 1.10 & 1.00 & 0.50 & 0.11 \\
3.12 & 0.55 & 0.50 & 0.10 & 0.02 \\
1.56 & 0.28 & 0.10 & 0.01 & 0.002 \\
\hline
\end{tabular}


agilis or $T$. viscana) were added to each replicate. The system was kept at $25 \pm 2^{\circ} \mathrm{C}$, under constant lighting and aeration, for 10 days. For $A$. agilis, $500 \mathrm{~mL}$ polyethylene flasks were used as test-chambers, filled with $200 \mathrm{~g}$ of sediment and $200 \mathrm{ml}$ of clean seawater, and fifteen organisms were exposed in each replicate. Samples were considered to be toxic when the survival averages were significantly lower than that exhibited by the animals exposed to the reference sediment (EC, 2001). The survival of the test-organisms in each sediment was compared to their respective controls, by the Student t'-test $(\mathrm{p} \leq 0.05)$. A Pearson correlation was used to assess the correspondence between both responses of amphipods and polychaetes.

\section{RESULTS}

In all the conducted experiments, the physicochemical parameters of overlying waters in the test-chambers (or test solutions, when it was the case) were evaluated at the beginning and at the end of exposure time, and $\mathrm{pH}$ (7.5-8.5), dissolved oxygen (DO) $\left(>5 \mathrm{mg} \mathrm{L}^{-1}\right)$ and salinity were within the acceptable levels according to the criteria established for T. viscana by Melo and Abessa (2002). Moreover, the toxicity test acceptance criteria (mean survival rates $\geq 80 \%$ on the controls) were achieved in all tests (USEPA 2002).

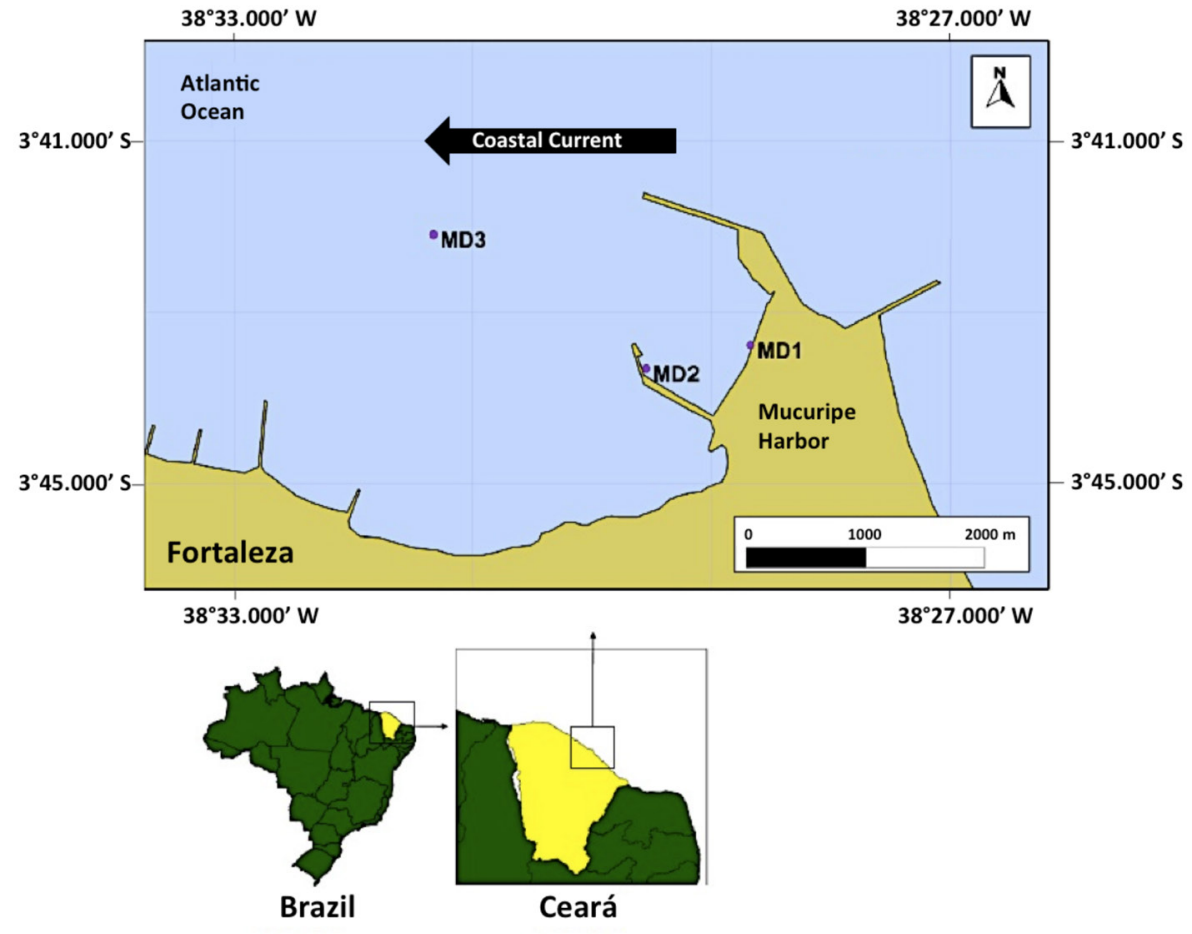

Figure 2: Map exhibiting the sediment sampling stations located close to the Mucuripe Harbor, Fortaleza-CE (during 2011). The black arrow indicates the direction of the predominant oceanic currents (Farias, 2008).

Table 2: Geographic coordinates, Depth and sedimentological characteristics (grain size distribution, organic matter and CaCO3 contents) of samples collected close to the Mucuripe Harbor (Fortaleza, CE, Brazil), during the dredging opreations (MD) and after dredging (MD'). The stations Ilhabela and Icapuí are considered reference samples, located on the coast of SP and CE, respectively. The textural classes were presented accordingly with Wentworth (1922).

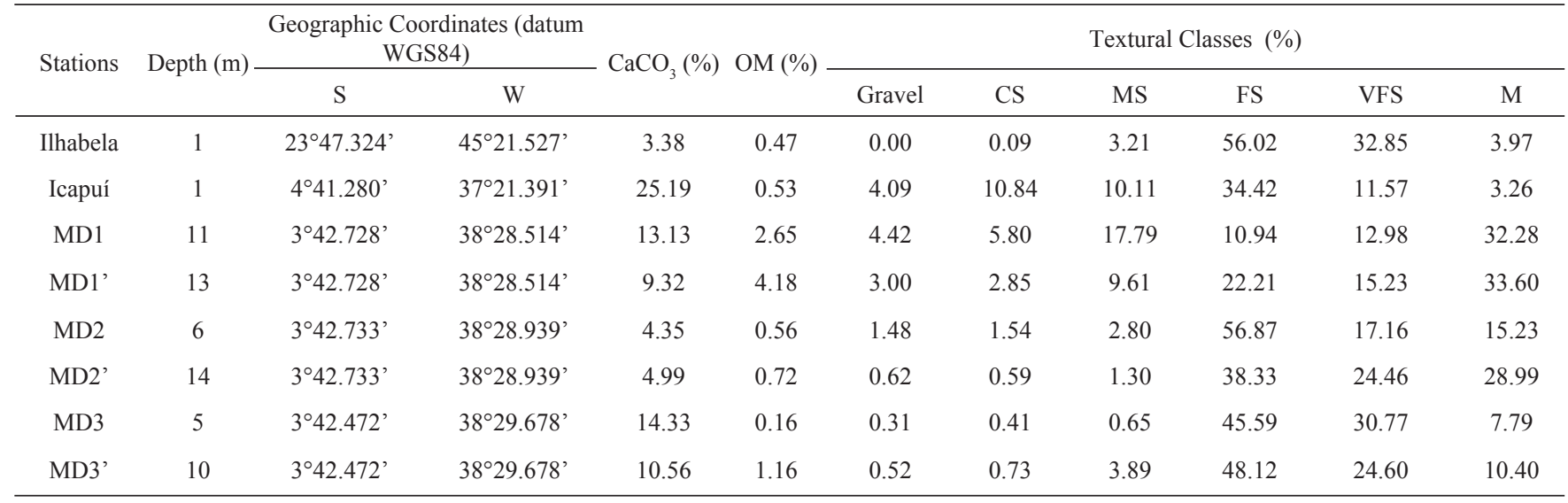

Note: $\mathrm{CaCO} 3$ - calcium carbonate; OM - organic matter; CS - coarse sand; MS - medium sand; FS - fine sand; VFS - very fine sand; M - mud (silt and clay). 


\section{Tolerance to Water Salinity}

The salinities range in our experiments (from 15 to 40) was defined in order to comprise estuarine and marine conditions. In the absence of sediments, the results showed significant reduction in survival of organisms exposed to salinities below 20 , after $72 \mathrm{~h}$. An optimum tolerance range remained between $35-25$, with survival means above $80 \%$ in all recordings.

The mean survivals were above $80 \%$ after 24 and 48 hours exposures. However at $96 \mathrm{~h}$, the mean survival rates were lower in all salinities $(<66.67 \%)$ (Figure 3$)$. In the experiment conducted with addition of sediments, (Figure 4) the results show significantly lower survivals at 20 and 15 salinities $(\mathrm{p}<0.05)$, confirming the results obtained in the test performed only with water.

\section{Tolerance to sediment textures}

The results of the bioassays with varying sediment grain sizes are presented in the Figure 5. The survival rates of $A$. agilis in each treatment containing the isolated pure fractions (medium, fine and very fine sands) were low when compared to the whole sediment from the reference site (pDunnett $\leq 0.05$ ). Animals exposed to muds presented a highly variable survival, which average was significantly low. On the other hand, animals exposed to coarse sand and gravel fractions presented survival above $60 \%$. This result indicates an effect promoted by the well-sorted condition. By analyzing the reference sample is possible to observe that fine sand isolated fraction (FS) corresponds to $56.02 \%$ of the total, followed by the very fine fraction to $32.85 \%$, characterized as fine sand (Table 2), in this condition the animals present good survival.

\section{Sensitivity to Reference substances}

For the three reference substances, the lethal concentrations to $50 \%$ organisms $\left(\mathrm{LC}_{50}\right)$ were calculated for 24 and 48 hours of exposure (Table 3). The greatest $\mathrm{LC}_{50}$ variation between two periods of exposure in a short-term test is called threshold or incipient $\mathrm{LC}_{50}$ (Buratini and Bertoletti, 2008; Rand et al., 1995).

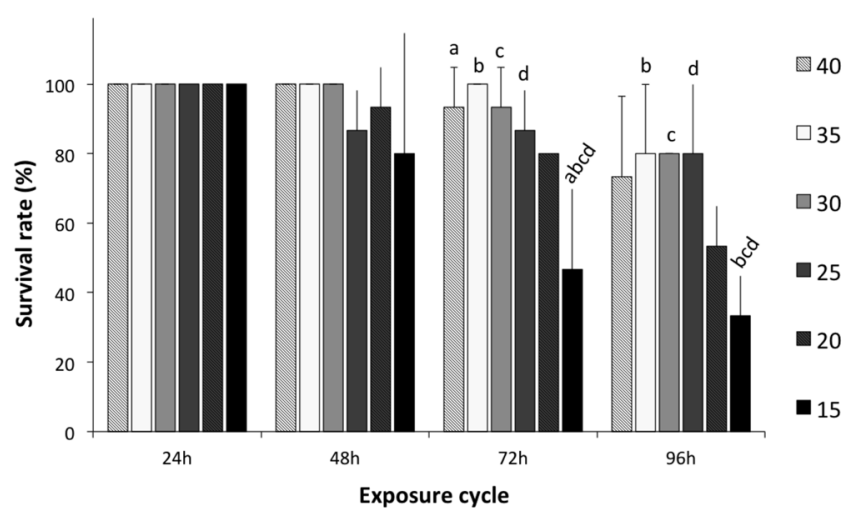

Figure 3: Mean survivals of the polychaete Armandia agilis maintained for 96 hours at different salinities. Different letters indicate significant difference in each cycle of exposure (ANOVA two-factor, pBonferroni $\leq 0.05)$.
Based on the results of 5 toxicity tests with the chosen reference substances, we constructed the respective initial control-charts based on the $\mathrm{LC}_{50}-48 \mathrm{~h}$ values to the polychaete A. agilis (Badaró-Pedroso et al., 2002; Rand et al., 1995). Upper and lower limits are determined by calculating $2 \mathrm{x}$ the standard deviation of the set of five $\mathrm{LC}_{50}$ values of each contaminant (Badaró-Pedroso et al., 2002; Buratini and Bertoletti, 2008). By comparing the contaminants tested, $\mathrm{Zn}$ and $\mathrm{Cr}$ were more toxic to A. agilis than the SDS (Table 3).

\section{Environmental samples}

Sediment properties of samples from Mucuripe collected during and after the dredging are presented in the table 2. In both surveys, high levels of mud composed the sediments from MD1, while sandy sediments occurred in MD2 and MD3. Levels of $\mathrm{CaCO}_{3}$ and $\mathrm{OM}$ followed the similar distribution of fine particles with the high values found in MD1. After dredging the levels of OM have raised at all sediment samples

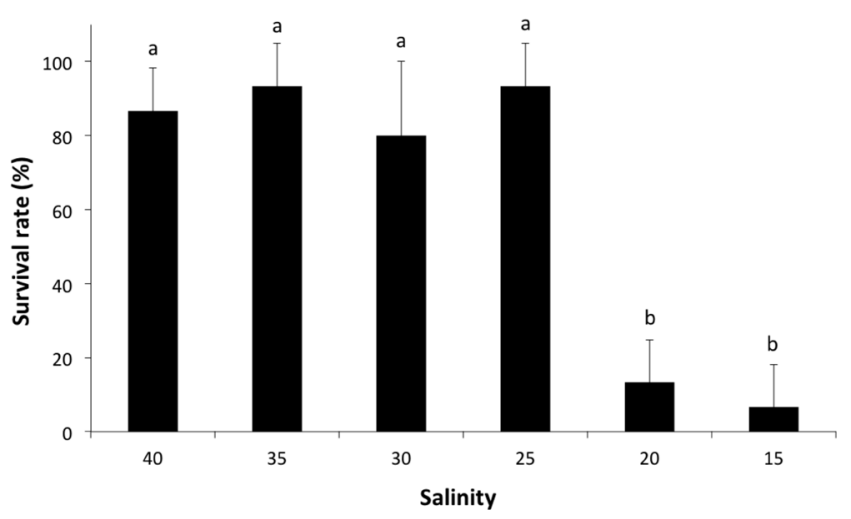

Figure 4: Mean survivals of Armandia agilis maintained in different salinities, after 10 days of exposure. Different letters indicate difference between treatments (ANOVA one-factor, pTukey $\leq 0.05$ ).

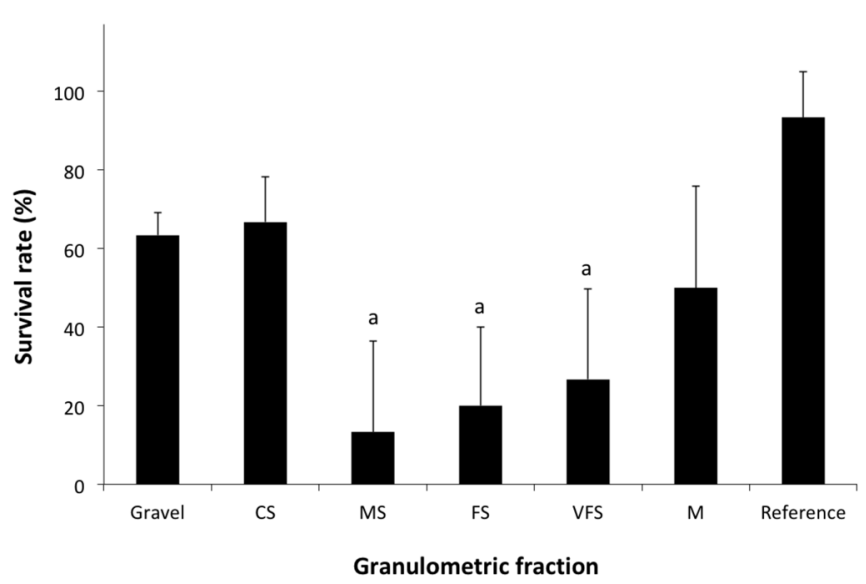

Figure 5: Mean survivals of Armandia agilis exposed to different sediment grain sizes, after 10 days. The letter ' $a$ ' indicates significant difference in relation to the reference sediment ( $\mathrm{pDunnett} \leq 0.05)$. CS - coarse sand; MS - medium sand; FS - fine sand; VFS - very fine sand; M - mud; Reference whole sediment of Ilhabela (control). 
Table 3: The average of lethal concentration for $50 \%\left(\mathrm{LC}_{50}\right)$ of the polychaete $A$. agilis exposed during cycle 24,48 , hours, as well as their upper and lower limits. Five assays were conducted to the reference substance zinc sulphate $\left(\mathrm{ZnSO}_{4}\right)$ and the detergent sodium dodecyl sulfate (SDS). Potassium dichromate $\left(\mathrm{K}_{2} \mathrm{Cr}_{2} \mathrm{O}_{7}\right)$ completed six assays tested. Mass stoichiometric conversions were used to adjust the test concentrations to metallic elements $\mathrm{Cr}$ and $\mathrm{Zn}$ (refer to Table 1).

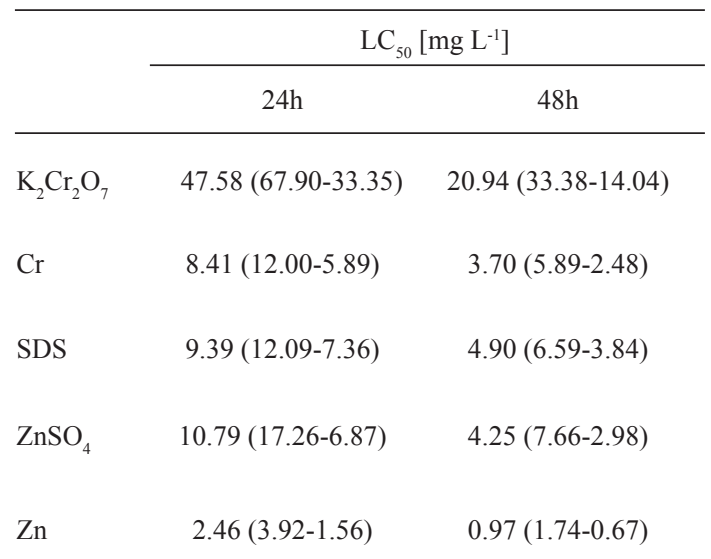

Note: The values in parentheses correspond to the upper and lower limits, respectively.

(MD1'; MD2' and MD3') while the concentrations of $\mathrm{CaCO}_{3}$ dropped in MD1' and MD3' (Table 2).

Regarding the results of the toxicity tests, for both exposed organisms, the sediments of Ilhabela induced the highest mean survival rates $(>80 \%)$. The survivals of the organisms exposed to sediments from Icapuí were lower, but did not significantly different from the rates obtained to the Ilhabela sediments (Figure 6). However, since the polychaetes exposed to sediments from Icapuí presented survival rates lower than those proposed in the international protocols for testing marine organisms (EC, 2001), we decided to use the sediments from Ilhabela as the reference sediment for further comparisons within this work.

The test with T. viscana evidenced toxicity for MD1, MD1', MD2 and MD3 (Figure 6). The polychaete A. agilis showed toxicity only for MD1 and MD1' (Figure 6). A Pearson correlation coefficient was calculated in order to associate the response of both species and the result produce a marginal significant relationship of both organisms (rPearson $=0.62$; $\mathrm{p}=0.055)$.

\section{DISCUSSION}

According to Rand et al. (1995), a model species is suitable to be used as test organism in ecotoxicological test according to some criteria such as: (I) wide distribution and abundance, (II) plays a key role in the ecological system or affected area (ecological and/or economic importance) (III) responds to chemical exposure; (IV) is easy to sample, acclimate, handle and cultivate or maintain in laboratory; and (V) presents a known biology, in terms of physiological, behavioral, demographic, ecological and genetic aspects. Armandia agilis is distributed along a large spatial extent of the Atlantic Ocean,

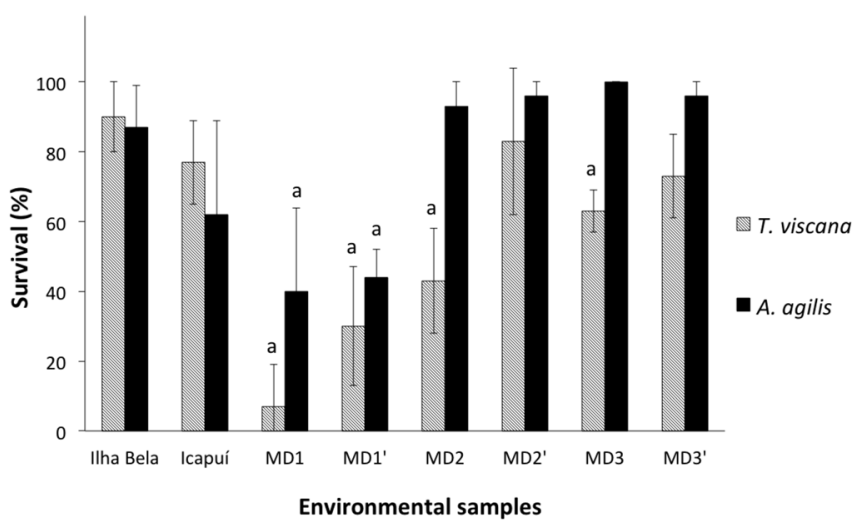

Figure 6: Averages of survival of two marine organisms exposed to sediments of Mucuripe Harbor, Fortaleza/CE. The letters ' $a$ ' indicate toxicity in relation to the reference sediment - Ilhabela (pStudent $\leq 0.05$ ). The statistical considerations were individual, each specie considered their respective survival in the reference.

from the North Carolina (USA) to the south of Brazil (Amaral et al., 2010; Nonato and Luna, 1970), and also occurs in Japan (Tamaki, 1985a). Additionally, a test-organism should be available to field sampling all over the year. In nature, $A$. agilis occupies substrates at depths ranging from $0.3 \mathrm{~m}$ to $100 \mathrm{~m}$ deep in muddy, sandy, and dendritic substrates (Amaral et al., 2010; Nonato and Luna, 1970) and is abundant all over the year. Along the Atlantic coast, juveniles are recruited during the summer, increasing their abundance (Nonato and Luna, 1970; Tamaki 1985b), whereas in the winter season, populations tend to be composed mostly by adults (Tamaki, 1985b). However, during this research, we have found both adult and juveniles of $A$. agilis in the Engenho d'Água Beach all along the year. Further studies should be conducted to determine the existence of fluctuations on the population composition of $A$. agilis, as this factor is relevant if toxicity tests are going to be routinely conducted.

The species tolerance to physical and chemical variables is of main concern when developing a new protocol for sediment toxicity testing. For marine benthic organisms, salinity and sediment texture are such main factors (Lewis and Watson, 2012), thus the species tolerances must be addressed. The tolerance of $A$. agilis to different salinities was evaluated in the presence and absence of sediments and the results showed low survival rates in mesohaline conditions (salinities $\leq 20$ ) (Figure 3).

Considering the short (96h) and long-term (10d) tests to evaluate species tolerance to salinities, we confirm the characteristics of the specie stenohaline, with the optimal range between 25 and 40 . Thus, the polychaete $A$. agilis does not fit well in estuarine situations, where there are abrupt salinity changes in short periods of time. Melo and Nipper (2007) also reported a reduction in the survival of the marine amphipod $T$. viscana exposed to salinities below 19. In their turn, Bat and Raffaelli (1998) suggested that seawater at 35 is suitable for conducting bioassays of toxicity with tropical species. The polychaete Polydora cornuta is tolerant to high salinities (25 to 30; see Pocklington and Wells, 1992), and 
sediment toxicity tests developed to this species recommends experiments to be performed at $28 \pm 2$ salinity (EC, 2001). For the polychaete Armandia brevis, the optimal recommended salinity in bioassays is $30 \pm 0.5$ (Meador and Rice, 2001). For toxicity tests using $A$. agilis, we suggest the use of natural or synthetic seawater (e.g., dilution water) with salinities higher than 25 , and if possible at the salinity range of $35 \pm 2$ (Table 5).

Sediment properties may interfere on the results of toxicity tests (Moreira et al., 2006; Rhee et al., 2012), because many benthic organisms, such as polychaetes, are sensitive to such variables. In such case, sediment properties can affect directly the survival of benthic organisms (Dean, 2008). In the test with the pure isolated sediment fractions, survival rates below $80 \%$ were observed for animals exposed to all fractions, being below $30 \%$ among animals exposed to medium, fine and very fine sands (Figure 5). Polychaetes exposed to pure muds presented low survival as well, with high inter-replicate variability $(50 \pm 25.8 \%)$. This would suggest that $A$. agilis is highly susceptible to sediment textures; however, unlike the fractions selected from the assay, in the natural environment the natural sediments are rarely composed of $100 \%$ of a single particle size. For the finer fractions (in special VFS, FS and Mud), it is possible that the organisms could barely deal with a more compacted substrate and low porosity (Selley, 1982), because under such condition the polychaetes would have some difficult to burrow. Thus, results from this bioassay suggest that young individuals of A. agilis prefer coarser sediments. However, in our study, this species was collected in the Engenho d'Água Beach, in sediments with predominance of fine sands (Table 2). As this sediment comprises also muddy particles, coarse sands and gravels, it can be considered heterogeneous, and allow the survival of A. agilis individuals. The sediment from Icapuí (the local reference site) was equally heterogeneous and presented a relevant percentage of calcareous bioclasts $\left(25.19 \% \mathrm{CaCO}_{3}\right)$, and the polychaetes exposed to these samples presented a slightly lower survival in comparison to sample from Ilhabela, which was not statistically different (Figure 6).

The fact of $A$. agilis is sensitive to pure sediment fractions prepared in laboratory may not constitute an obstacle to its use as a test-organism. The amphipod Tiburonella viscana was also considered sensitive to $100 \%$ muddy and coarse sediments (Melo and Nipper, 2007), but it is widely used for testing laboratory and field sediments (Buruaem et al., 2017), based on the fact that environmental samples are rarely composed by only one type of grain size. Besides, regarding environmental samples, there is rarely a reduction in survival due to texture (Roberts, 2012). However, under these conditions, it is possible that the sediment texture may be a confounding factor to A. agilis and this aspect should be well addressed if the species is used in sediment toxicity testing.

Another relevant factor for a test-organism is its sensitivity to contaminants. In this study, we exposed $A$. agilis juveniles to an organic compound (SDS) and two metals (Table 3) in order to verify their sensitivity to such chemicals, expressed by the $\mathrm{LC}_{50}$ values, and compare it to other invertebrate species used in aquatic ecotoxicology. For the SDS and potassium dichromate, these comparisons could be made considering the substances, whereas for the zinc sulfate, since studies regarding the substance are scarce, a stoichiometric mass balance was made in order to estimate the zinc toxicity, based on the nominal concentrations. For the contaminants evaluated, the $\mathrm{LC}_{50}-48 \mathrm{~h}$ values were within the ranges obtained in other studies using sensitive benthic organisms (Table 4), reinforcing that $A$. agilis is a potential test organism.

Despite the stigma of being pollution tolerant due to the opportunistic characteristic of some species, the sensitivity of polychaetes has been well documented (Allen et al., 2007; Anderson et al., 1998; Bat, 2005; Bat and Raffaelli, 1998; Mayor et al., 2008; Millward et al., 2005). Given the ecological importance of the group these results show that the sensitivity of polychaetes to contaminants can be comparable to other sensitive groups, depending on the species of polychaete considered.

Finally, a test-organism for sediment toxicity tests should be able to respond to the sediment contamination and discriminate toxic and non-toxic conditions based on the presence of pollutants. In this study, the sediments used in the validation experiments were collected close to the Mucuripe Harbor (Fortaleza, Ceará State, NE Brazil) which is located in a metropolitan region with more than two million people. This port comprises a terminal from an oil refinery and also passed through a dredging process during our sampling campaigns. Sediments from Icapuí (clean site) were tested as an additional reference, considering its textural profile, which is representative of the Brazilian Northeast coast (Buruaem et al., 2012; Nilin et al., 2013).

The sediments from the stations situated in the shade portion of the Mucuripe Harbor of the port (MD1, MD1', MD2 and MD2') were more muddy, organically enriched and contaminated by metals and hydrocarbons (Buruaem et al., 2016) (Figure 2; Table 1). The sediment from MD1 exhibited the highest concentration of $\mathrm{Hg}, \mathrm{Pb}, \mathrm{Cr}, \mathrm{Cu}, \mathrm{Ni}$ and $\mathrm{Zn}$ (Buruaem et al., 2017), whereas MD2 presented intermediary levels, with lower concentrations in MD3 (Buruaem et al., 2012). After the dredging process the MD1' sample was still toxic to both organisms tested. The samples from MD1 and MD1' were toxic to $A$. agilis, while these sediments and those from MD2 and MD3 (during the dredging) were toxic to amphipod. The samples from MD2' and MD3' were not toxic to both organisms (Figure 6). Buruaem et al. (2017) evaluated the same sampling sites during the dredging period and found low survival rates for $T$. viscana exposed to sediments from MD1, MD2 and MD3; their results were very similar to those obtained by us to both species during the same sampling period. Thus, we inferred that the responses of $T$. viscana and $A$ agilis were relatively comparable, and that $A$. agilis was able to respond to contaminated sediments.

However, some differences were found, since A. agilis individuals were affected by sediments of only one site during dredging (MD1), while sediments from all sites caused 
Table 4: Lethal concentrations to $50 \%$ exposed organisms $\left(\mathrm{LC}_{50}\right)$ for several species exposed to three contaminants used as reference substances (potassium dichromate, sodium dodecyl sulfate and zinc). The values are based on the respective nominal concentrations.

\begin{tabular}{|c|c|c|c|c|c|c|}
\hline Species & Taxonomic group & Contaminant & $\begin{array}{l}\text { Exposure } \\
\text { time }(\mathrm{h})\end{array}$ & $\begin{array}{c}\text { Temperature } \\
\left({ }^{\circ} \mathrm{C}\right)\end{array}$ & $\begin{array}{c}\mathrm{LC}_{50} \\
{\left[\mathrm{mg} \mathrm{L}^{-1}\right]}\end{array}$ & References \\
\hline Armandia agilis & Polychaeta & \multirow{9}{*}{$\mathrm{K}_{2} \mathrm{Cr}_{2} \mathrm{O}_{7}$} & 24 & 25 & $47.58(67.90-33.35)$ & This study \\
\hline A. agilis & Polychaeta & & 48 & 25 & $20.94(33.38-14.04)$ & This study \\
\hline Tisbe longicornis & Copepoda & & 48 & 20 & 10 & Larrain et al., 1998 \\
\hline Tisbe biminiensis & Copepoda & & 48 & 25 & $22.22(24.30-19.92)$ & Araújo-Castro et al., 2009 \\
\hline T. biminiensis & Copepoda & & 72 & 25 & $13.84(17.56-10.12)$ & Araújo-Castro et al., 2009 \\
\hline T. biminiensis & Copepoda & & 96 & 25 & $9.45(11.13-7.77)$ & Araújo-Castro et al., 2009 \\
\hline Tiburonella viscana & Amphipoda & & 48 & 23 & $6.09(3.27-11.12)$ & Abessa et al., 1998 \\
\hline T. viscana & Amphipoda & & 48 & 25 & $5.85(4.9-7.0)$ & Melo and Nipper, 2007 \\
\hline T. viscana & Amphipoda & & 48 & 25 & $11.2(7.4-14.7)$ & Abessa and Souza, 2003 \\
\hline Armandia agilis & Polychaeta & \multirow{5}{*}{ SDS } & 24 & 25 & $9.39(12.09-7.36)$ & This study \\
\hline A. agilis & Polychaeta & & 48 & 25 & $4.90(6.59-3.84)$ & This study \\
\hline Acartia tonsa & Copepoda & & 48 & 20 & 1.45 & Perina, 2009 \\
\hline Mysidopsis juniae & Mysidacea & & 96 & 25 & 2.36 & Perina, 2009 \\
\hline M. juniae & Mysidacea & & 96 & 25 & $1.85(1.58-2.17)$ & Ihara, 2008 \\
\hline Armandia agilis & Polychaeta & \multirow{4}{*}{$\mathrm{Zn}$} & 24 & 25 & $2.46(3.92-1.56)$ & This study \\
\hline A. agilis & Polychaeta & & 48 & 25 & $0.97(1.74-0.67)$ & This study \\
\hline Dinophilus gyrociliatus & Polychaeta & & 96 & 24 & 1.0 & Mauri et al., 2003 \\
\hline D. gyrociliatus & Polychaeta & & 96 & 25 & 0.2 & Reish and Gerlinger, 1997 \\
\hline
\end{tabular}

Note: The $\mathrm{LC}_{50}$ data is followed by the confidence intervals between parentheses.

toxicity to T. viscana. Differences of sensitiveness between polychaetes and amphipods were previously reported in the literature (Millward et al., 2005), and could be attributed to several factors, as the dietary habit, contact with sediment particles, ingestion of sediments, among others (Melo and Abessa, 2002; Melo and Nipper, 2007; Nonato and Luna, 1970; Tamaki, 1985a). Similarly to our research, some authors reported higher sensitivity of amphipods (Bat and Raffaelli, 1998; Anderson et al., 1998), but they strongly recommended the extensive use of the worm, as it was representative of a range of environments. In summary, amphipods and polychaetes have been used in ecotoxicological experiments, and although such benthic organisms have the same patterns of toxicity, punctual responses may be quite different (Anderson et al., 1998; Bat and Raffaelli, 1998; Millward et al., 2005).

The table 5 summarizes the conditions for sediment bioassays using $A$. agilis. We suggest the use of a minimum of 4 replicates with 5 to 10 organisms each, in order to provide a greater robustness to the statistical analysis (Badaró-Pedroso et al., 2002).

\section{CONCLUSIONS}

Based on the results, we concluded that A. agilis, which seems to be a typical marine burrowing polychaete, fulfill the majority of pre-requisites to be a test-organism in ecotoxicological studies. The species presents broad geographic distribution, is available in field for all over the year and present good tolerance to laboratory handling and conditions. It is sensitive to contaminants, in a range similar to other marine invertebrates used in ecotoxicological studies. Despite its sensitivity to some pure sediment fractions, this species inhabits heterogeneous substrates, rich in fine and very fine sands. Moreover, when exposed to field-collected sediments with different ranges of pollution, this species is able to discriminate clean and contaminated samples, in a comparable way than a sensitive amphipod. Because of this set of characteristics, we conclude that Armandia agilis may be considered a suitable test-organism for ecotoxicological studies with marine sediments.

\section{ACKNOWLEDGEMENTS}

This research was funded by the grant \#2010/07605-7 from the São Paulo Research Foundation (FAPESP), by the Research Support Foundation of Ceará State (FUNCAP, grant number 1571/07 and BMD-0008-00058.01.18/09) and the Brazilian National Research Council (CNPQ, grant number 142002/2010-0). We also thank the support from the NEPEA's staff, especially MSc. Giuliana Araújo (currently at University of Aveiro) and Biol. Tainá Fonseca (currently at University of Algarve). We are also grateful to the Drs. Cecilia do Amaral (UNICAMP), Veronica de Oliveira (UFPR) and Paulo da Cunha Lana(UFPR). 
Table 5: Summary of the general conditions of the bioassay proposed with a tropical zone sensitive polychaete, A. agilis. The conditions were established for the whole sediment test as well as reference substance (sensitivity test).

\begin{tabular}{|c|c|c|}
\hline & \multicolumn{2}{|c|}{ Armandia agilis (Polychaeta) } \\
\hline & Bioassay reference substance & Acute bioassay of whole sediment \\
\hline Test type & Acute - Static & Acute - Static \\
\hline Dilution water & Reconstituted or filtered seawater $(0.45 \mu \mathrm{m})$ & Reconstituted or filtered seawater $(0.45 \mu \mathrm{m})$ \\
\hline Sediment type & - & Sandy \\
\hline Temperature & $25 \pm 2^{\circ} \mathrm{C}$ & $25 \pm 2^{\circ} \mathrm{C}$ \\
\hline Salinity ranges & $>20$, preferably $35 \pm 2$ & $>20$, preferably $35 \pm 2$ \\
\hline Light intensity & lighting $( \pm 500$ lux $)$ & lighting $( \pm 500$ lux $)$ \\
\hline Photoperiod & $12 \mathrm{~h}: 12 \mathrm{~h}$ (clear/dark) & 12h:12h (clear/dark) \\
\hline Areation & Not necessary & intense and constant \\
\hline Capacity of bottle test & $250-500 \mathrm{~mL}$ & $500-1000 \mathrm{~mL}$ \\
\hline Volume of diluition water & $150-300 \mathrm{~mL}$ & $300-700 \mathrm{~mL}$ \\
\hline Amount of sediment test & - & $200 \mathrm{~g}$ \\
\hline Number of organisms / bottle test & $5-10$ & $10-20$ \\
\hline Number of replicates & At least 4 & At least 4 \\
\hline Duration test & $48 \mathrm{~h}$ & 10 days \\
\hline Feeding & No & No \\
\hline Parameters controlled & $\mathrm{pH}$ among $7.5-8.5$ & $\mathrm{pH}$ among $7.5-8.5$ \\
\hline (start and finish of test) & Dissolved oxygen $>5 \mathrm{mg} \mathrm{L}^{-1}$ & Dissolved oxygen $>5 \mathrm{mg} \mathrm{L}^{-1}$ \\
\hline Endpoint & Lethality & Lethality \\
\hline Validation test & Minimum $80 \%$ survival in control & Minimum $80 \%$ survival in control \\
\hline Expression results & $\mathrm{LC}_{50}-48 \mathrm{~h}$ & Survival (\%) \\
\hline
\end{tabular}

\section{REFERENCES}

ABESSA, D.M.S., CARR, R.S., RACHID, B.R.F., SOUSA, E.C.P.M., HORTELANI, M.A., SARKIS, J.E., 2005. Influence of a Brazilian sewage outfall on the toxicity and contamination of adjacent sediments. Mar. Pollut. Bull. 50: 875-885. DOI: 10.1016/j.marpolbul.2005.02.034

ABESSA, D.M.S., CARR, R.S., SOUSA, E.C.P.M., RACHID, B.R.F., ZARONI, L.P., GASPARRO, M.R., PINTO, Y.A., BICEGO, M.C., HORTELLANI, M.A., SARKIS, J.E.S., MUNIZ, P., 2008. Integrative ecotoxicological assessment of contaminated sediments in a complex tropical estuarine system, in: Hofer, T. N. (Ed.), Marine pollution: new research. Nova Science Publishers Inc., New York, pp. 36.

AHRENS, M.J., HERTZ, J., LAMOUREUX, E.M., LOPEZ, G.R., MCELROY, A.E., BROWNAWELL, B.J., 2001. The effect of body size on digestive chemistry and absorption efficiencies of food and sediment-bound organic contaminants in Nereis succinea (Polychaeta). J. Exp. Mar. Biol. Ecol. 263: 185-209. DOI 10.1016/S0022-0981(01)00305-7

ALLEN, Y.T., THAIN, J.E., HAWORTH, S., BARRY, J., 2007. Development and application of long-term sublethal whole sediment tests with Arenicola marina and Corophium volutator using Ivermectin as the test compound. Environ. Pollut. 146: 9299. DOI 10.1016/j.envpol.2006.06.007

AMARAL, A.C.Z., 1980. Anelídeos poliquetos do infralitoral em duas enseadas da região de ubatuba. Bolm. inst. oceanogr. 29: 69-87. DOI 10.1590/S0373-55241980000100006

AMARAL, A.C.Z., BORZONE, C.A., 2008. Macrofauna bentônica: praias do Sudeste e Sul do Brasil. Boletim Associação Brasileira Biologia Marinha 1: 6-19.

AMARAL, A.C.Z., MIGOTTO, A.E., TURRA, A., SCHAEFFERNOVELLI, Y., 2010. Araçá: biodiversidade, impactos e ameaças. Biota Neotropica 10: 219-264.

ASTM (American Society For Testing Materials), 2000. E156200: Standard guide for conducting acute, chronic, and lifecycle aquatic toxicity tests with polychaetous annelids. ASTM International, West Conshohocken.

ASTM (American Society For Testing Materials), 2004. E1850-04: Standard guide for selection of resident species as test organisms for aquatic and sediment toxicity tests. ASTM International, West Conshohocken.

ASTM (American Society For Testing Materials), 2007. E161107: Standard guide for conducting sediment toxicity tests with Polychaetous Annelids. ASTM International, West Conshohocken.

ANDERSON, B.S., HUNT, J.W., PHILLIPS, B.M., TUDOR, S., FAIREY, R., NEWMAN, J., PUCKETT, H.M., STEPHENSON, M., LONG, E.R., TJEERDEMA, R.S., 1998. Comparison of marine sediment toxicity test protocols for the amphipod Rhepoxynius abronius and the polychaete worm Nereis (Neanthes) arenaceodentata. Environ. Toxicol. Chem. 17: 859866. DOI 10.1002/etc.5620170513

ARAÚJO-CASTRO, C.M.V., SOUZA-SANTOS, L.P., TORREIRO, A.G.A.G., GARCIA, K.S., 2009. Sensitivity of the marine benthic copepod Tisbe biminiensis (Copepoda, Harpacticoida) to potassium dichromate and sediment particle size. Braz. J. Oceanogr. 57: 33-41. DOI 10.1590/S1679-87592009000100004 
ABNT (Associação Brasileira De Normas Técnicas), 2016. NBR15638:2016: Aquatic ecotoxicology: Acute toxicity: Test method in sediment with marine and estuarine amphipods. ABNT, São Paulo.

BADARÓ-PEDROSO, C., REYNIER, M.V., MELO, S.L.R., 2002. Garantia de qualidade e precauções com segurança e saúde em laboratórios de ecotoxicologia aquatic, in: Nascimento, I.A., Sousa, E.C.P.M., Nipper, M. (Eds.), Métodos em ecotoxicologia marinha: aplicações no Brasil. Artes Gráficas, São Paulo, pp. 2650 .

BAT, L., 2005. A review of sediment toxicity bioassays using the Amphipods and Polychaetes. Turk. J. Fish. Aquat. Sci. 5: 119139.

BAT, L., RAFFAELLI, D., 1998. Sediment toxicity testing: a bioassay approach using the amphipod Corophium volutator and the polychaete Arenicola marina. J. Exp. Mar. Biol. Ecol. 226: 217-239. DOI 10.1016/S0022-0981(97)00249-9

BAY, S., GREENSTEIN, D., YOUNG, D., 2007 Evaluation of methods for measuring sediment toxicity in California Bays and estuaries. Southern California Coastal Water Research Project, Costa Mesa, pp. 96.

BEYER, J., PETERSEN, K., SONG, Y., RUUS, A., GRUNG, M., BAKKE, T., TOLLEFSEN, K.E., 2014. Environmental risk assessment of combined effects in aquatic ecotoxicology: a discussion paper. Mar. Environ. Res. 96: 81-91. DOI 10.1016/j. marenvres.2013.10.008

BEZERRA, M.O., PINHEIRO, L., MORAIS, J.O., 2007. Shoreline change of the Mucuripe Harbour zones (Fortaleza-Ceará, Northeast of Brazil) 1972 - 2003. J. Coast. Res. 50: 1163-1167.

BLAISE, C., 1984. Introduction to ecotoxicological concepts: proceeding of biological testing and hazard assessment. Environment Canada 20-21: 11-47.

BRENDOLAN, R.A., 2004. Utilização do microcrustáceo Kalliapseudes schubartii em testes de ecotoxicologia. Universidade Federal Fluminense, Rio de Janeiro, pp. 107.

BURATINI, S.V., BERTOLETTI, E., 2008. Análise estatística, in: Zagatto, P. A., Bertoletti, E. (Eds.), Ecotoxicologia aquática: princípios e aplicações, second ed. RiMa, São Carlos, pp. 221249.

BURTON JR., G.A., SCOTT, K.J., 1992. Sediment toxicity evaluations: their niche in ecological assessment. Environ. Sci. Technol. 26: 2068-2075. DOI 10.1021/es00035a002

BURUAEM, L.M., HORTELLANI, M.A., SARKIS, J.E., COSTALOTUFO, L.V., ABESSA, D.M.S., 2012. Contamination of port zone sediments by metals from Large Marine Ecosystems of Brazil. Mar. Pollut. Bull. 64: 479-488. DOI 10.1016/j. marpolbul.2012.01.017.

BURUAEM, L.M., CASTRO, I.B., HORTELLANI, M.A., TANIGUCHI, S., FILLMANN, G., SASAKI, S.T., PETTI, M.A.V., SARKIS, J.E.S., BÍCEGO, M.C., MARANHO, L.A., DAVANSO, M.B., NONATO, E.F., CESAR, A., COSTALOTUFO, L.V., ABESSA, D.M.S., 2013. Integrated quality assessment of sediments from harbour areas in Santos-São Vicente Estuarine System, Southern Brazil. Estuar. Coast. Shelf. Sci. 130: 179-189. DOI 10.1016/j.ecss.2013.06.006

BURUAEM, L.M., TANIGUCHI, S., SASAKI, S.T., BÍCEGO, M.C., COSTA-LOTUFO, L.V., ABESSA, D.M.S., 2016. Hydrocarbons in surface sediments of harbor areas in a tropical region (Ceará state, northeast Brazil). Environ. Earth Sci. 75:642, 1-10. DOI 10.1007/s12665-016-5453-4

BURUAEM, L.M., CASTRO, Í.B., HORTELLANI, M.A., SASAKI, S.T., TANIGUCHI, S., PETTI, M.A.V., FILLMANN, G., SARKIS, J.E.S., BÍCEGO, M.C., COSTA-LOTUFO, L.V., ABESSA, D.M.S., 2017. Effects of harbor activities on sediment quality in a semi-arid region in Brazil. Ecotoxicol. Environ. Saf. 135: 137-151. DOI 10.1016/j.ecoenv.2016.09.020.

CHAPMAN, P.M., 1989. Current approaches to developing sediment quality criteria. Environ. Toxicol. Chem. 8: 589-599. DOI 10.1002/etc.5620080706

CHAPMAN, P.M., 2002. Integrating toxicology and ecology: putting the "eco" into ecotoxicology. Mar. Pollut. Bull. 44: 7-15. DOI 10.1016/S0025-326X(01)00253-3

CHAPMAN, P.M., 2007. Determining when contamination is pollution: weight of evidence determinations for sediments and effluents. Environ. Int. 33: 492-501. DOI 10.1016/j. envint.2006.09.001

CHAPMAN, P.M., SMITH, M., 2012. Assessing, managing and monitoring contaminated aquatic sediments. Mar. Pollut. Bull. 64: 2000-2004. DOI 10.1016/j.marpolbul.2012.07.023

DAUVIN, J., RUELLET, T., 2009. The estuarine quality paradox: Is it possible to define an ecological quality status for specific modified and naturally stressed estuarine ecosystems? Mar. Pollut. Bull. 59: 38-47. 10.1016/j.marpolbul.2008.11.008

DEAN, H.K., 2008. The use of polychaetes (Annelida) as indicator species of marine pollution: a review. Rev. Biol. Trop. 56: 11-38. DOI 10.15517/rbt.v56i4.27162

DEWITT, T.H., SWARTZ, R.S., HANSEN, D.J., MCGOVERN, D., BERRY, W.J., 1996. Bioavailability and chronic toxicity of cadmium in sediment to the estuarine amphipod Leptocheirus plumulosus. Environ. Toxicol. Chem. 15: 2095-2101. DOI $10.1002 /$ etc. 5620151205

DILLON, T.M., MOORE, D.W., 1993. The relationship between growth and reproduction in the marine polychaete Nereis (Neanthes) arenaceodentata (Moore): implications for chronic sublethal sediment bioassays. J. Exp. Mar. Biol. Ecol. 173: 231246. DOI 10.1016/0022-0981(93)90055-S

EC (Environment Canada), 2001. EPS1/RM/41: Biological test method: Test for survival and growth in sediment using Spionid Polychaete worms (Polydora cornuta). Canadian Environmental Assessment Agency, Ottawa.

FARIAS, E.G.G., 2008. Aplicação de técnicas de geoprocessamento para a análise da evolução da linha de costa em ambientes litorâneos do estado do Ceará. Universidade Federal do Ceará, Fortaleza, pp. 123.

FAUCHALD, K., JUMARS, P.A., 1979. The diet of worms: a study of polychaete feeding guilds. Oceanography Marine Biology Annual Review 17: 193-284.

FOLK, R.L., WARD, W.C., 1957. Brazos river bar: a study in the significance of grain size parameters. J. Sediment. Petrol. 27: 3-26. DOI 10.1306/74D70646-2B21-11D7-8648000102C1865D

FRENCH, B., TURNER, A., 2008. Mobilization, adsorption, and bioavailability of Pt and Pd in coastal sediments: the role of the polychaete, Arenicola marina. Environ. Sci. Technol. 42: 35433549. DOI 10.1021/es071693n

GALLOWAY, T., LEWIS, C., DOLCIOTTI, I., JOHNSTON B.D., MOGER J., REGOLI F., 2010. Sublethal toxicity of nanotitanium dioxide and carbon nanotubes in a sediment dwelling marine polychaete. Environ Pollut. 158: 1748-1755. DOI 10.1016/j.envpol.2009.11.013

GOMIERO, A., DAGNINO, A., NASCI, C., VIARENGO, A., 2013. The use of protozoa in ecotoxicology: application of multiple endpoint tests of the ciliate E. crassus for the evaluation of sediment quality in coastal marine ecosystems. Sci. Total Environ. 442: 534-544. DOI 10.1016/j.scitotenv.2012.10.023

GROSS, M.G., 1971. Carbon determination, in: Carver, R.E. (Ed.), Procedures in sedimentary petrology. Wiley-Interscience, NewYork, pp. 573-596.

HAMILTON, M.A., RUSSO, R.C., THURSTON, R.V., 1977. 
Trimmed Spearman-Karber method for estimating median lethal concentrations in toxicity bioassays. Environ. Sci. Technol. 11: 714-719. DOI 10.1021/es60130a004

IHARA, P.M., 2008. Aplicação de ensaios ecotoxicológicos com diferentes organismos-teste na determinação da toxicidade da água produzida. Universidade Federal de Rio Grande, Rio Grande, pp. 98.

KUK-DZUL, J.G., GOLD-BOUCHOT, G., ARDISSON, P.L., 2012. Benthic infauna variability in relation to environmental factors and organic pollutants in tropical coastal lagoons from the northern Yucatan Peninsula. Mar. Pollut. Bull. 64: 2725-2733. DOI 10.1016/j.marpolbul.2012.09.022

KWOK, K.W.H., BATLEY, G.E., WENNING, R.J., ZHU, L., VANGHELUWE, M., LEE, S., 2014. Sediment quality guidelines: challenges and opportunities for improving sediment management. Environ. Sci. Pollut. Res. Int. 21: 17-27. DOI 10.1007/s11356-013-1778-7

LAMBERSON, J.O., DEWITT, T.H., SWARTZ, R.C., 1992. Assessment of sediment toxicity to marine benthos, in: Burton Jr., G.A. (Ed.), Sediment toxicity assessment. Lewis Publishers, Chelsea, pp: 183-211.

LARRAIN, A., SOTO, E., SILVA, J., BAY-SCHMITH, E., 1998. Sensitivity of the meiofaunal copepod Tisbe longicornis to $\mathrm{K}_{2} \mathrm{Cr}_{2} \mathrm{O}_{7}$ under varying temperature regimes. Bull. Environ. Contam. Toxicol. 61: 391-396.

LAVORANTE, B.R.B.O., OLIVEIRA, D.D., COSTA, B.V.M., SOUZA-SANTOS, L.P., 2013. A new protocol for ecotoxicological assessment of seawater using nauplii of Tisbe biminiensis (Copepoda:Harpacticoida). Ecotoxicol. Environ. Saf. 95: 52-59. DOI 10.1016/j.ecoenv.2013.05.010

LEWIS, C., POOK, C., GALLOWAY, T., 2008. Reproductive toxicity of the water accommodated fraction (WAF) of crude oil in the polychaetes Arenicola marina (L.) and Nereis virens (Sars). Aquat. Toxicol. 90: 73-81. DOI 10.1016/j.aquatox.2008.08.001

LEWIS, C., WATSON, G.J., 2012. Expanding the ecotoxicological toolbox: the inclusion of polychaete reproductive endpoints. Mar. Environ. Res. 75: 10-22. DOI 10.1016/j.marenvres.2011.08.002

LONG, E.R., MACDONALD, D.D., SMITH, S.L., CALDER, F.D., 1995. Incidence of adverse biological effects within ranges of chemical concentrations in marine and estuarine sediments. Environ. Manage. 19: 81-97. DOI 10.1007/BF02472006

LONG, E.R., HONG, C.B., SEVERN, C.G., 2001. Relationships between acute sediment toxicity in laboratory tests and abundance and diversity of benthic infauna in marine sediments: a review. Environ. Toxicol. Chem. 20: 46-60. DOI 10.1002/ etc. 5620200105

LOTUFO, G.R., ABESSA, D.M.S., 2002. Testes de toxicidade com sedimento total e água intersticial estuarinos utilizando copépodos bentônicos, in: Nascimento, I.A., Sousa, E.C.P.M., Nipper, M. (Eds.), Métodos em ecotoxicologia marinha: aplicações no Brasil. Editora Artes Gráficas e Indústria Ltda, São Paulo, pp. 151-162.

LUCZAK, C., JANQUIN, M., KUPKA, A., 1997. Simple standard procedure for the routine determination of organic matter in marine sediment. Hydrobiologia 345: 87-94. DOI 10.1023/A:1002902626798

MAIA, L.P., JIMENEZ, J.A., SERRA, J., MORAIS, J.O., 1998. The coastline of Fortaleza City: a product of environmental impacts caused by the Mucuripe Harbor. Arquivos Ciências Mar 31: $93-$ 100 .

MARANHO, L.A., ABREU, I., SANTELLI, R., CORDEIRO, R.C., SOARES-GOMES, A., MOREIRA, L.B., MORAIS, R.D., ABESSA, D.M.S., 2009. Sediment toxicity assessment of Guanabara Bay, Rio de Janeiro, Brazil. J. Coast. Res. 56: 851-
855.

MATTHIESSEN, P., BIFIELD, S., JARRETT, F., KIRBY, M.F., LAW, R.J., MCMINN, W.R., SHEAHAN, D.A., THAIN, J.E., WHALE, G.F., 1998. An assessment of sediment toxicity in the River Tyne Estuary, UK by means of bioassays. Mar. Environ. Res. 45: 1-15. DOI 10.1016/S0141-1136(96)00098-0

MAURI, M., BARALDI, E., SIMONINI, R., 2003. Effects of zinc exposure on the polychaete Dinophilus gyrociliatus: a life-table response experiment. Aquat Toxicol. 65: 93-100. DOI 10.1016/ S0166-445X(03)00109-7

MAYOR, D.J., SOLAN, M., MARTINEZ, I., MURRAY, L., MCMILLAN, H., PATON, G.I., KILLHAM K., 2008. Acute toxicity of some treatments commonly used by the salmonid aquaculture industry to Corophium volutator and Hediste diversicolor: whole sediment bioassay tests. Aquaculture 285: 102-108. DOI 10.1016/j.aquaculture.2008.08.008

MCDONALD, B.G., HAYNES, P.A., 2001. Silica sand as an artificial control sediment in a 20 day Neanthes arenaceodentata toxicity test. Environ. Toxicol. 16: 172-176. DOI 10.1002/tox.1021

MEADOR, J.P., RICE, C.A., 2001. Impaired growth in the polychaete Armandia brevis exposed to tributyltin in sediment. Mar. Environ. Res. 51: 113-129. DOI 10.1016/S0141-1136(00)00033-7

MELO, S.L.R., ABESSA, D.M.S., 2002. Testes de toxicidade com sedimentos marinhos utilizando anfípodos, in: Nascimento, I.A., Sousa, E.C.P.M., Nipper, M. (Eds.), Métodos em ecotoxicologia marinha: aplicações no Brasil. Artes Gráficas, São Paulo, pp. 163-178.

MELO, S.L.R., NIPPER, M., 2007. Sediment toxicity tests using the burrowing amphipod Tiburonella viscana (Amphipoda: Platyschinopidae). Ecotoxicol. Environ. Saf. 66: 412-420. DOI 10.1016/j.ecoenv.2005.12.003

MILLWARD, R.N., BRIDGES, T.S., GHOSH, U., ZIMMERMAN, J.R., LUTHY, R.G., 2005. Addition of activated carbon to sediments to reduce PCB bioaccumulation by a polychaete (Neanthes arenaceodentata) and an amphipod (Leptocheirus plumulosus). Environ. Sci. Technol., 39: 2880-2887. DOI $10.1021 /$ es048768x

MOLISANI, M.M., COSTA, R. N., CUNHA, P., REZENDE, C.E., FERREIRA, M.I.P., ESTEVES, F.A., 2013. Acute toxicity bioassay with the amphipod, Grandidierella bonnieroides S. after exposure to sediments from an urban estuary (Macaé River Estuary, RJ, Brazil). Bull. Environ. Contam. Toxicol. 90: 79-84. DOI 10.1007/s00128-012-0871-9

MOREIRA, S.M., LIMA, I., RIBEIRO, R., GUILHERMINO, L., 2006. Effects of estuarine sediment contamination on feeding and on key physiological functions of the polychaete Hediste diversicolor: laboratory and in situ assays. Aquat Toxicol. 78: 186-201. DOI 10.1016/j.aquatox.2006.03.001

NILIN, J., MOREIRA, L.B., AGUIAR, J.E., MARINS, R., ABESSA, D.M.S., LOTUFO, T.M.C., COSTA-LOTUFO, L.V., 2013. Sediment quality assessment in a tropical estuary: the case of Ceará River, Northeastern Brazil. Mar. Environ. Res. 91: 8996. DOI 10.1016/j.marenvres.2013.02.009

NONATO, E.F., LUNA, J.A., 1970. Anelideos poliquetas do nordeste do Brasil: poliquetas bentonicos da costa de Alagoas e Sergipe. Bolm. inst. oceanogr. 19: 57-130. DOI 10.1590/S037355241970000100004

OLIVEIRA, D.D., SOUZA-SANTOS, L.P., SILVA, H.K.P., MACEDO, S.J., 2014. Toxicity of sediments from a mangrove forest patch in an urban area in Pernambuco (Brazil). Ecotoxicol. Environ. Saf. 104: 373-378. DOI 10.1016/j.ecoenv.2014.02.004

OMENA, E.P., LAVRADO, H.P., PARANHOS, R., SILVA, T.A., 2012. Spatial distribution of intertidal sandy beach polychaeta along an estuarine and morphodynamic gradient in an eutrophic 
tropical bay. Mar. Pollut. Bull. 64: 1861-1873. DOI 10.1016/j. marpolbul.2012.06.009

PERINA, F.C., 2009. Avaliação da toxicidade de biocidas utilizados em tintas anti-incrustantes. Universidade Federal do Rio Grande, Rio Grande, pp. 123.

PESCH, C.E., 1979. Influence of three sediment types on copper toxicity to the polychaeta Neanthes arenaceodentata. Mar. Biol. 52: 237-245. DOI 10.1007/BF00398137

POCKLINGTON, P., WELLS, P.G., 1992. Polychaetes: key taxa for marine environmental quality monitoring. Mar. Pollut. Bull. 24: 93-598. DOI 10.1016/0025-326X(92)90278-E

RAMOS-GÓMEZ, J., MARTÍN-DÍAZ M.L., RODRÍGUEZ, A., RIBA, I., DELVALLS, T.A., 2008. In situ evaluation of sediment toxicity in Guadalete Estuary (SW Spain) after exposure of caged Arenicola marina. Environ Toxicol. 23: 643-651. DOI 10.1002/ tox. 20416

RAND, G.M., WELLS, P.G., MCCARTY, L.S., 1995. Introduction to aquatic toxicology, in: Rand, G.M. (Ed.), Fundamentals of aquatic toxicology: effects, environmental fate, and risk assessment, second ed. CRC Press, Boca Raton, pp. 3-67.

REISH, D.J., GERLINGER, T.V., 1997. A review of the toxicological studies with Polychaetous annelids. Bull. Mar. Sci. 60: 584-607.

RHEE, J.S., WON, E.J., KIM, R.O., CHOI, B.S., CHOI, I.Y., PARK, G.S., SHIN, K.H., LEE, Y.M., LEE, J.S., 2012. The polychaete, Perinereis nuntia ESTs and its use to uncover potential biomarker genes for molecular ecotoxicological studies. Environ. Res. 112: 48-57. DOI 10.1016/j.envres.2011.09.012

ROBERTS, D.A., 2012. Causes and ecological effects of resuspended contaminated sediments (RCS) in marine environments. Environ. Int. 40: 230-243. DOI 10.1016/j.envint.2011.11.013

SELLEY, R.C., 1982. An introduction to sedimentology, second ed. Academic Press, Orlando, pp. 480.

SENESE, V., BORIANI, E., BADERNA, D., MARIANI, A., LODI, M., FINIZIO, A., TESTA, S., BENFENATI, E., 2010. Assessing the environmental risks associated with contaminated sites: definition of an ecotoxicological classification index for landfill areas (ECRIS). Chemosphere 80: 60-66. DOI 10.1016/j. chemosphere.2010.03.035

SILVA, G.S., 2007. Filogenia de Opheliidae (Annelida: Polychaeta). Universidade Federal do Paraná, Curitiba, pp. 107.

SOUSA, E.C.P.M., ZARONI, L.P., FILHO, T.U.B., MARCONATO, L.A., KIRSCHBAUM, A.A., GASPARRO, M.R., 2012. Acute sensitivity to Nitokra sp benthic copepod to potassium dichromate and ammonia chloride. Ecotoxicol. Environ. Contam. 7: 75-81.
DOI 10.5132/jbse.2012.01.011

SUN, F., ZHOU, Q., WANG, M., AN, J., 2009. Joint stress of copper and petroleum hydrocarbons on the polychaete Perinereis aibuhitensis at biochemical levels. Ecotoxicol. Environ. Saf. 72: 1887-1892. DOI 10.1016/j.ecoenv.2009.04.017

TAMAKI, A., 1985a. Inhibition of larval recruitment of Armandia sp. (Polychaeta: Opheliidae) by established adults of Pseudopolydora pauczbranchzata (okuda) (Polychaeta: Spionidae) on an intertidal sand flat. J. Exp. Mar. Biol. Ecol. 87: 61-82. DOI 10.1016/0022-0981(85)90193-5

TAMAKI, A., 1985b. Zonation by size in the Armandia sp. (Polychaeta: Ophaeliidae) population on an intertidal sand flat. Mar. Ecol. Prog. Ser. 27: 123-133.

TORRES, R.J., ABESSA, D.M.S., SANTOS, F.C., MARANHO, L.A., DAVANSO, M. B., NASCIMENTO, M.R.L., MOZETO, A.A., 2009. Effects of dredging operations on sediment quality: contaminant mobilization in dredged sediments from the Port of Santos, SP, Brazil. J. Soils Sediments 9: 420-432. DOI 10.1007/ s11368-009-0121-x

UGLAND, K.I., BJØRGESÆTER, A., BAKKE, T., FREDHEIM, B., GRAY, J.S., 2008. Assessment of environmental stress with a biological index based on opportunistic species. J. Exp. Mar. Biol. Ecol. 366: 169-174. DOI 10.1016/j.jembe.2008.07.021

USEPA (United States Environmental Protection Agency), 1996. EPA/712/C-96/355: Ecological effects test guidelines OPPTS 850.1740: Whole sediment acute toxicity invertebrates, marine. USEPA, Cincinnat.

USEPA (United States Environmental Protection Agency), 2002. EPA/821/R-02/014: Short-term methods for estimating the chronic toxicity of effluents and receiving waters to marine and estuarine organisms. USEPA, Cincinnat.

VENTURINI, N., MUNIZ, P., BÍCEGO, M.C., MARTINS, C.C., TOMMASI, L.R., 2008. Petroleum contamination impact on macrobenthic communities under the influence of an oil refinery: integrating chemical and biological multivariate data. Estuar. Coast. Shelf. Sci. 78: 457-467. DOI 10.1016/j.ecss.2008.01.008

WATSON, G.J., PINI, J., LEACH, A., FONES, G., 2013. Longterm incubation of adult Nereis virens (Annelida: Polychaeta) in copper-spiked sediment: the effects on adult mortality, gametogenesis, spawning and embryo development. Aquat Toxicol. 128-129: 1-12. DOI 10.1016/j.aquatox.2012.11.015

WENTWORTH, C.K., 1922. A scale of grade and class terms for clastic sediments. Journal Geology 30: 377-392. 